\title{
Convergent Literary Echoes in Kafka's \\ Die Verwandlung. What Intertextuality Tells \\ Us about Gregor Samsa
}

For Samaneh Gachpazian

Wo aber Gefahr ist, wächst das Rettende auch

The entomological dogma prevailing in Kafka scholarship and the whole world of literary criticism, according to which Die Verwandlung relates the metamorphosis of Gregor Samsa into a monstrous vermin (bug), has proved incapable of unraveling the complexity of Kafka's most widely known work. In a series of articles, I have declared myself a heretic regarding that dogma, and I have argued that there is indeed a key for solving the interpretative riddle of Die Verwandlung. The solution lies in realizing that this novella contains two conflicting versions of the events - one according to which Gregor is a subhuman being, and another in which he is a human being, and also in considering the complexity of the victimary processes and the cognitive distortions that they entail, and paying attention to the manifold moral conflicts of the characters in Kafka's most celebrated story. Once a careful reading of the text has been made, Die Verwandlung turns out to be the text in which Kafka has reflected the formation process of a phenomenon of "corrupt objectivity", namely, the phenomenon which takes place in a victimary circle when the unanimity of the persecutors has been obtained, the victim has internalized the version of the victimary circle, and there are no independent spectators who could say that the victimary version is a distorted truth. ${ }^{1}$ And this leads us to conclude,

${ }^{1}$ For a detailed explanation of this concept ("corrupt objectivity") and its utility for solving the riddle of Die Verwandlung, see Bermejo-Rubio 2010: 155-160; and especially Bermejo-Rubio, Grete Samsa's inconsistent 
Convergent Literary Echoes in Kafka's Die Verwandlung

in turn, that Gregor Samsa, for the Prague writer and for the characters in the story, is nothing but a human being. The aim of the present article is to survey the most plausible results obtained in the study of Kafka's story from the perspective of intertextuality, in order to prove that they support my reading.

Among the several myths and wrong ideas surrounding Kafka's work, one of them has been that of absolute and unmitigated originality. This idea has been rightly challenged by several scholars, whose investigations have proved that Kafka incorporated literary texts into his own writings (even when we find no mention of such texts or their authors in his Diaries and letters). Even if nobody can deny the extent of this writer's originality, it is possible to conclude that "Kafka was a synthetic writer [...] his greatest works were built on frames supplied by other authors" (Spilka 1980: 289). ${ }^{2}$ Kafka's own statements allow us to track this path. For instance, regarding his unfinished novel Der Verschollene, which he began to write two months before having composed Die Verwandlung, the Prague writer himself noted in his Diaries that it is "sheer imitation" of Dickens" David Copperfield. ${ }^{3}$

It is crucial to realize that, despite so many claims about the alleged impact of fairy tales and fantastic literature such as Ovid's

speech. The logic underlying the two conflicting versions in Kafka's Die Verwandlung, forthcoming.

${ }^{2}$ Regarding Die Verwandlung, I have argued elsewhere that the use of the image of lasting dirt in the third part of the story betrays a(n) (im)moral atmosphere characterized by the presence of impurity and remorse, and that this motif has probably been taken from Shakespeare's Macbeth (a work which is also cited in Flaubert's L'Éducation sentimentale, one of Kafka's favorite literary works). We have a sort of Kafkaesque equivalent of the Shakespearean image in Macbeth especially in Mr. Samsa's uniform (which is dirty in spite of all his wife's and sister's care); see Bermejo-Rubio 2011: 96-97.

3 “'Dickens Copperfield. 'Der Heizer' glatte Dickensnachahmung, noch mehr der geplante Roman. Koffergeschichte, der Beglückende und Bezaubernde, die niedrigen Arbeiten, die Geliebte auf dem Landgut die schmutzigen Häuser u.a. vor allem aber die Methode. Meine Absicht war wie ich jetzt sehe einen Dickensroman zu schreiben, nur bereichert [...]" (T 841). 
BERMEJO-RUBIO

Metamorphosis (see Heselhaus 1952: 353f; Beicken 1983: 69) or Apuleius' The Golden Ass on Die Verwandlung, no scholar has been able to prove it. ${ }^{4}$ This is a particularly important point, given that the widespread entomological dogma invites us to think of the presence of such Vorlagen or pre-texts. Of course, other proposals - such as the one claiming that Die Verwandlung is an adaptation of the Medieval German epic Gregorius by Hartmann von Aue- ${ }^{5}$ have revealed, at best, only very superficial similarities and are not convincing. Some of these proposals, however, deserve attention. The most plausible ones are examined below.

\section{Jacob Gordin, Der wilde Mensch}

It is well known that between October 1911 and February 1912 Kafka repeatedly attended in Prague's Café Savoy many (about a dozen) performances of a Yiddish theater troupe from Eastern Europe, led by Jizchak Löwy; ${ }^{6}$ his Diaries are full of testimony of his

${ }^{4}$ Binder is right on this point: "Im Blick auf mögliche literarische Vorlagen zur Verwandlung ist zu sagen, daß keinerlei direkter genetischer Zusammenhang mit Ovids Metamorphosen und vergleichbaren Verwandlungsvorgängern im Märchen besteht, wie in der Nachfolge von C. Heselhaus [...] oft behauptet wurde" (Binder 1975: 155-156). The same could be said, however, about the alleged relationship between Die Verwandlung and the animal stories by the Danish writer Johannes V. Jensen (pace Binder 1983: 156-159; Binder 2004: 60-65).

${ }^{5}$ Politzer 1962: 77; Weinberg 1963: 237-239; Köhnke 1971; Winkelman 1983. Winkelman's article, for instance, is a magnificent example of the arbitrariness so often displayed in Kafka scholarship, insofar as it is based on the assumption that "Gregor Samsa is imprisoned in his room for seventeen months, just as Gregorius was chained to his rock for seventeen years". Unfortunately, this assumption is wrong, as Kafka's story develops from an indeterminate moment in autumn (probably November - December) to the next spring (end March), so not for 17 months at all, but only for 3,4 or 5 .

${ }^{6}$ It is interesting to recall that Kafka's father said to his son about Löwy: "Wer sich mit Hunden legt steht mit Wanzen auf" (T 223). In his "Brief an den Vater", eight years later, Kafka was to say: "Ohne ihn zu kennen, verglichst $\mathrm{Du}$ ihn in einer schrecklichen Weise, die ich schon vergessen 
attendance and his enthusiasm for those performances. At the beginning of 1912, on the occasion of a Löwy performance, he even gave a public address in Prague on the Yiddish language. Evelyn T. Beck has argued that Kafka's breakthrough as a writer in the fall of 1912 is intimately linked with this experience (Beck 1970; Beck 1971). More precisely, this scholar has noted the many parallelisms between Die Verwandlung and a classic of the Yiddish theater, Jacob Gordin's Der vilder Mensh (Der wilder Mensch). ${ }^{7}$ Kafka attended the performance of this piece on October 24, 1911, and in his Diaries (October, 26 and 28, 1911) discusses it at length, outlining its plot in some detail. ${ }^{8}$

The similarities are indeed striking. Both are stories focused on a family (the Samsas and the Layblikhs), and the centrality of Gregor in Die Verwandlung closely parallels that of Lemekh, "the savage one" in Gordin's play. ${ }^{9}$ Both the Samsas and the Layblikhs are similarly to blame for their sons' declines: both sons are treated unfairly and without compassion, they are barely tolerated in the home, looked upon with disgust as outcasts whose very existence shames their families. They lie in their own rooms, and whenever either Lemekh or Gregor tries to join his family, he is shooed into his designated quarters and beaten by an enraged father. Both experience a process of progressive physical and psychological decay, and in fact both "crawl on the floor", which provides a direct and visual statement of the extent of their degradation. ${ }^{10}$ Both conceal themselves when they hear their relatives coming, and, like Lemekh,

habe, mit Ungeziefer". Gregor Samsa sees himself "zu einem ungeheueren Ungeziefer verwandelt".

7 This work was also Löwy's "Lieblingswerk"; he was photographed as Lemekh (see e.g. Wagenbach $1994^{3}$ : 152).

${ }^{8}$ T 196. Gordin seems to have been Kafka's favorite Yiddish author: "Gordon [sic] ist deshalb besser als Lateiner, Scharkansky, Feimann u.s.w. weil er mehr Details, mehr Ordnung und mehr Folgerichtigkeit in dieser Ordnung hat" (T 195).

${ }^{9}$ Five main characters in Die Verwandlung (father, mother, son, daughter and maid) have direct parallels in Gordin's work. See Beck 1971: 136-146. 10 "Er krikht oyf der erd"; "Gregor kroch noch ein Stück vorwärts und hielt den Kopf eng an den Boden" (DL 185). 
BERMEJO-RUBIO

Gregor is grateful to be allowed to look at and listen to his family from the darkness of his room. In story and play alike, the son's transformation manifests itself in a loss of verbal communication (Lemekh's speech takes on the quality of a weeping groan). Both are described by similar epithets: Gregor is called by his mother "mein unglücklicher Sohn" (DL 159), and Lemekh is described as "the unsuccessful son" (der nit gerutene zun). Their psychological destruction reaches the point that they consider their deaths the best solution for them and their families. ${ }^{11}$

A particularly significant feature in common is that Gregor and Lemekh are presented as persons who become animal-like creatures as a result of drastic transformations. In this sense, it is a revealing fact that Lemekh, like Gregor, is compared to an animal and to a sacrificial victim. Gregor is obviously animalized from the very beginning of Kafka's novella, insofar as he perceives himself at the beginning as Ungeziefer, and also later, when his sister describes him as an animal (Tier) and a monster (Untier) ${ }^{12}$ moreover, Gregor calls himself a "victim" (Opfer). ${ }^{13}$ Regarding Lemekh, it is said that he is vi a hun in bney adam. This is a revealing expression - and, by the way, a nice example of the composite nature of Yiddish -: vi a hun corresponds to the German "wie ein Huhn"; bney adam is the Hebrew-Aramaic bene Adam, whose meaning is "sons of Adam", which is an evident Semitism for "men". Therefore, the expression applied to Lemekh means "like a hen among men". And this is aptly translated by E. T. Beck as "like an animal waiting to be sacrificed", insofar as the hen is a reference to the chicken (a white hen or a white rooster) that is to be sacrificed on Yom Kippur. Both protagonists, therefore, are clearly designated as victims.

\footnotetext{
${ }^{11}$ Lemekh says: "Far mir un far aykh volt besser geven az ikh zol shtarbn (For me and for you it would be better if I died)". The narrative voice says about Gregor: "Seine Meinung darüber, daß er verschwinden müsse, war womöglich noch entschiedener, als die seiner Schwester" (DL 193).

${ }^{12}$ DL $189-191$.

${ }^{13}$ DL 136.
} 
Convergent Literary Echoes in Kafka's Die Verwandlung

\section{Fyodor M. Dostoyevsky, The Double}

In a letter to Felice Bauer, written some months after having written Die Verwandlung, Kafka refers to the four human beings he considers his "true relatives" (meine eigentlichen Blutsverwandten); besides Grillparzer, Kleist and Flaubert, he also mentions Dostoyevsky. ${ }^{14}$ It is not surprising, therefore, that we find echoes of this writer in Kafka's works. In fact, several scholars have studied the echoes of The Double (Dvoynik: Peterburgskaya poema) which are to be found in Die Verwandlung. ${ }^{15}$ This work of the Russian novelist centers on a government clerk, Yakov Petrovitch Golyadkin, who feels excluded from society; the novella, accordingly, depicts the sufferings of Mr. Golyadkin and his humiliated human dignity. Golyadkin behaves as a man on the verge of madness and then perceives a double appear before him, a man who looks exactly like him and bears his name, thus personifying his illness.

The very beginning of The Double presents striking correspondences with that of Die Verwandlung. Golyadkin wakes up from a long sleep, but he lies in his bed not being quite certain whether he is awake or still asleep and whether all that is going on around him is real and genuine, or the continuation of his confused dreams. Just like Gregor, Golyadkin pays attention first to the walls of his room (and the room is described as "small"), then to some objects in the room, and finally to the window, where - just as Gregor - he discovers a damp autumn day. Immediately afterwards, both protagonists close their eyes and try to sleep again. ${ }^{16}$

Other significant parallels emerge in the fourth and the fifth chapters. Golyadkin tries to attend a party at the home of his former

${ }^{14}$ September 2, 1913 (Br II: 275). For Dostoyevsky's works in Kafka's library, see Born 1990: 30-34.

${ }^{15}$ Spilka 1959: 291-298; Binder 2004: 85, 95, 131, 277. The alleged echoes of Gogol's works in Die Verwandlung (Ehrlich 1956; Parry 1962) could be more easily explained through Dostoyevsky's reception of Gogol.

${ }^{16}$ In the 6th chapter, when Golyadkin perceives his double, he wonders if he is in a dream, and the narrative voice says: "no, it was not a dream". Also the narrative voice in Die Verwandlung states: "Es war kein Traum" (DL 115). 
BERMEJO-RUBIO

protector, the councilor Berendyev, precisely on the day when the birthday of Berendyev's daughter, Klara Olsufyevna, is celebrated with a dance and music. In this scene, several parallels to the third part of Die Verwandlung are perceptible. Golyadkin stands in a dark corner, in the midst of rubbish, litter, and odds and ends of all sorts, "concealing himself for the time being and watching the course of proceedings as a disinterested spectator". He is "in expectation of a happy ending to his adventures". At a certain moment, he dashes into the midst of a social meeting to which he has not been invited. The other people, however, react by rejecting him, and "Golyadkin felt himself an insect". He claims a dance with Klara, but he is again rejected. Then Golyadkin is unceremoniously taken by some hands and guided straight to the door, swept away, and thrown out. It is after having had this experience of stark humiliation that complete loss of self-esteem, shame and the figure of the double appear.

Apart from the opening paragraph of both stories, there are obvious parallels between them: both heroes suffer from the effects of social exclusion and lack of affection, both must conceal themselves in the midst of rubbish because of the shame and the fear of being rejected, both are psychologically degraded through this very concealment, both see themselves as vermin, both imagine a happy ending to their unhappiness, both appear before other characters during a social meeting (a dance with orchestra in the case of The Double, and a violin performance in Die Verwandlung), and both are actually rejected by a young girl (Golyadkin by Klara, and Gregor by Grete - who will condemn him to death at the end of the story -).

\section{Leopold von Sacher-Masoch, Venus im Pelz}

Several scholars have highlighted the possible links of Die Verwandlung with Sacher-Masoch's Venus im Pelz (Angress 1970; Waldeck 1972; Kuna 1972; Anderson 1988; pace Binder 2004: 130131). This work, originally published as part of the collection Das Vermächtnis Kains in 1870, relates a story of a man's complete submission. The protagonist, the aristocrat Severin von Kusiemski, persuades his mistress, Wanda von Dunajew, to treat him as her 
servant and slave, and he even signs a written contract obligating himself totally to her. The first obvious link with Kafka's novella is the fact that both are stories of a man's virtually complete self-denial and submission to other people. Kafka's is also a story of the complete submission of Gregor to his family. As Severin is financially dependent on his father and then his mistress, so Gregor is financially dependent on his father, even if he earns the money. ${ }^{17}$ Both Gregor and Severin lead a life indiscernible from that of a servant: Severin travels with Wanda as her servant to Italy; Gregor works himself into the ground for his family, and his parents believe he will be set for life in his unsatisfactory job. ${ }^{18}$

Another significant coincidence lies in the similarity of names of the main characters. The name of Sacher Masoch's protagonist is Severin, but when he decides to give himself over to Wanda's whims, he is renamed Gregor by his sadistic and pitiless mistress as part of his subjugation and degradation: "Sie heißen von nun an nicht mehr Severin, sondern Gregor". Regarding the family name "Samsa", P. B. Waldeck has pointed to the possibility that it could be determined by the letters mas[och] (backwards) and sa[cher], from the compound family name of the author of Venus im Pelz (Waldeck 1972: 147-148; Rudloff 1997: 16f).

Even if scholars have emphasized the alleged Masochistic contents in Kafka's story, I do not agree completely with this view. What is undoubtedly relevant, however, is the fact that both protagonists are humiliated and treated with increasing brutality: in the case of Severin/Gregor, this brutality consists largely of frequent whippings by his mistress and long periods in which he is not allowed to see her; in Gregor's case, it consists of several physical injuries from his father, and progressive abandonment by his sister and mother. This entails a degrading process which results in the fact that they both are compared to animals, and even to objects.

17 "Das Geld, das Gregor allmonatlich nach Hause gebracht hatte - er selbst hatte nur ein paar Gulden für sich behalten [...]" (DL 154).

18 "Die Eltern [...] hatten sich in den langen Jahren die Überzeugung gebildet, daß Gregor in diesem Geschäft für sein Leben versorgt war" (DL 137). 
BERMEJO-RUBIO

Severin/Gregor is described as an "animal" (Tier), a "worm" (Wurm), and a "dog" (Hund), but also as a mere object (lebloses Ding), a toy (Spielzeug), and a nothing (Nichts). Gregor is also called an "animal" (Tier) by his sister, sees himself as a vermin (Ungeziefer) and his corpse is described by the cleaning woman as an object (Zeug).

Another common point in both stories is the importance of a lady in furs. Sacher Masoch's main character emphasizes throughout the novel that it is specifically the furs that excite and appeal to his eroticism (as it is clearly pointed out in the very title, Venus im Pelz). In Die Verwandlung, the most significant object in Gregor's room is the picture of a lady done up in a fur hat and a fur boa, sitting upright and raising up a heavy fur muff. The great significance of this object is perceptible not only in the fact that it is mentioned on the first page of the story, but also in that it is referred to again twice, one of them at a crucial point: when Gregor's mother and sister are removing the furniture from his room, Gregor leaves his hiding place under the couch and clings to the picture, daring anyone to attempt to remove it. The depiction of this scene makes it clear that there exist some kind of erotic ties between Gregor and the fur-clad woman in the picture. ${ }^{19}$

An interesting link between Kafka's and Sacher Masoch's works can be detected, although not on the level of the explicit contents. At the end of the story, Severin/Gregor is bound and whipped not only by his lover, but also by his rival Apollo, and then they both abandon him. But precisely this terrible end "cures" Severin/Gregor, who learns "the moral of the tale": "whoever allows himself to be whipped, deserves to be whipped" ("Daher die Moral der Geschichte: wer sich peitschen läßt, verdient, gepeitscht zu werden"). Such a lesson seems not to have been learned by Gregor Samsa, but by Kafka himself. Die Verwandlung is indeed a kind of

19 "Er wußte wirklich nicht, was er zuerst retten sollte, da sah er an der im übrigen schon leeren Wand auffallend das Bild der in lauter Pelzwerk gekleideten Dame hängen, kroch eilends hinauf und preßte sich an das Glas, das ihn festhielt und seinem heißen Bauch wohltat. Dieses Bild wenigstens, das Gregor jetzt ganz verdeckte, würde nun gewiß niemand wegnehmen." (DL 165). 
Convergent Literary Echoes in Kafka's Die Verwandlung

caveat or cautionary tale, through which Kafka observes his possible destiny if he were to yield to his family's demands to work at their asbestos factory. In this sense, Gregor Samsa represents an alter ego in which Kafka has embodied his own weakness and feelings of guilt.

\section{Charles Dickens, David Copperfield}

As we have seen, Kafka himself remarked that he was thinking of Dickens' David Copperfield at the time of writing Der Verschollene. Given that Kafka wrote Die Verwandlung only a few weeks later, there are good reasons to presume that the famous novel of the English author could have left its stamp also on the best known of Kafka's short stories, all the more because in Dickens the parental theme predominates. This has been indeed argued by Mark Spilka, who has presented a plausible case (Spilka 1959: 298-305).

This literary relationship is especially discernable in a scene from Chapter 4 of David Copperfield. Simply for having botched his spelling lesson, David is brutally whipped by his stepfather, who is actually the household tyrant. After vainly trying to defend himself David bites Murdstone's hand, and then he is beaten again and locked in his room for five days. The description of his captivity resembles in many aspects that of Kafka's protagonist ("imprisonment", "Gefangenschaft"). Like Gregor Samsa, David is shut off from his family after a household commotion; like Gregor, he is beaten by the parental authority; like Gregor, he is compared to an animal (an "obstinate horse or dog"); like Gregor, he is lying upon the floor; like Gregor, he crawls up from the floor to a glass; like Gregor, he experiences deep guilt feelings ("the guilt [...] lay heavier on my breast than if I had been a most atrocious criminal, I dare say"); like Gregor, it is difficult for him to recognize himself ("I crawled up from the floor, and saw my face in the glass, so swollen, red and ugly that it almost frightened me"); like Gregor, he is provided food by a woman (even the first meal is similar); like Gregor, he is kept from his mother; like Gregor, David is ashamed to show himself at the window; like Gregor, he has the strange sensation of never hearing himself speak; like Gregor, his time sense 
BERMEJO-RUBIO

is deranged ("The length of those days I can convey no idea to anyone; they occupy the place of years in my remembrance"); like Gregor, he is deprived of his possessions. In these and other details, David Copperfield's experience recalls that of Gregor Samsa.

\section{New Testament Writings}

Even if Kafka was a Jew, the Samsa family is not Jewish, but an unmistakably Christian family (although religion is not an important matter for them); this is proved by the references to the saints, to Christmas and to the fact that, when his relatives and the cleaning woman see Gregor's corpse, they all cross themselves. ${ }^{20}$ Of course, Kafka knew well the mythical interpretation of the first century Palestinian Jew Jesus of Nazareth offered by the Gospels and, more generally, the New Testament and the Christian tradition, according to which Jesus is a divine figure whose death has a universal soteriological meaning. ${ }^{21}$

The most interesting thing here is that, in that victim which is Gregor Samsa, it is easy to discern some echoes of the mythical Christ of the Christian tradition. "Kafka has given Gregor a number of Christ-like attributes" (Holland 1958: 147; Wokenfeld 1970). There are, of course, the following general similarities: just as Christ takes on the "guilt" (Schuld) of the whole world, Gregor had taken on the responsibility of working for the whole family, working himself into the ground to pay back his parents' debt (Schuld meaning both "debt" and "guilt"). Just as Jesus is abandoned by his disciples and betrayed three times by Peter, Gregor is progressively abandoned by his relatives, and the three times he goes out of his room he is rejected. Just as Jesus is presented by New Testament

\footnotetext{
20 ''Nun', sagte Herr Samsa, 'jetzt können wir Gott danken.' Er bekreuzte sich, und die drei Frauen folgten seinem Beispiel.” (DL 195).

${ }^{21}$ In the summer of 1912, during his stay in Jungborn (Harz), Kafka met a certain Hitzer, "mit dem ich mich heuer im Sommer recht gut befreundet hatte und der mich in ganzem, langen Nachmittagen zu Jesus hatte bekehren wollen", as he writes to Felice Bauer (Br I: 245). Incidentally, this letter is dated November $18^{\text {th }}$, just one day after Kafka had begun to write Die Verwandlung.
} 
Convergent Literary Echoes in Kafka's Die Verwandlung

writers as Isaiah's Lord's servant ${ }^{22}$ and so as a figure "despised and rejected of men, a man of sorrows and acquainted with grief", Gregor's pains and sufferings are alluded to throughout the story. ${ }^{23}$ Just as Jesus is slandered at his passion and becomes the victim of an (at least from the perspective of the Gospel writers) unfair process, so also Gregor is the victim of unfounded accusations (by the manager of the firm and his own sister) throughout the text. Just as in the New Testament faith's formulae Jesus is considered as an animal (a sheep or a lamb) which is taken to the slaughter (John 1:29; Acts $8: 32=$ Is $53: 7 ; 1$ Peter $1: 19 ; 1$ Corinthians 5:7), so Gregor is featured as an animal and a victim. And just as Jesus is seen as a scapegoat who bears the sins and weakness of the humankind in his own body (see 1 Peter 2:24), Gregor's dirty body reflects the guilt represented by the abandonment he suffers: "[...] war auch er ganz staubbedeckt; Fäden, Haare, Speiseüberreste schleppte er aufseinem Rücken und an den Seiten mit sich herum". ${ }^{24}$

The parallels become even more evident in the final part of the story and in the description of Gregor's death. Just as, according to the Gospels, darkness covers the earth before Jesus' death (Mark 15:33 and parallels), so darkness reigns around Gregor ("und sah sich im Dunkeln um": DL 193). Just as Jesus is immobilized on the cross, Gregor also realizes that he "could no longer move at all". 25 Just as Jesus experiences solitude and is forsaken, Gregor dies

${ }^{22}$ The New Testament writers, and the whole Christian tradition, have interpreted the figure of Jesus in terms of Isaiah's Suffering Servant (Is 52:13 53:12; see 1 Peter 2:21-25).

${ }^{23}$ In the first pages of the story we already find many references to Gregor's Schmerzen (see DL 116, 120, 121, 125, 131). Later, his Leiden (DL 138) and his leidender Zustand (DL 191) are mentioned.

${ }^{24}$ DL 184. 'Dies scheint ein Wörtlichnehmen des Begriffs 'Sündenbock' zu sein. Ebenso wie der ursprüngliche Träger des Wortes, ist Gregor mit dem Abfall (den Sünden) der Gemeinschaft behängt” (Kiefer 1979: 271).

${ }^{25}$ In another passage referring to Gregor's being "nailed down" ("Gregor wollte sich weiterschleppen, als könne der überraschende unglaubliche Schmerz mit dem Ortswechsel vergehen; doch fühlte er sich wie festgenagelt": DL 171), Ronald Gray has seen an allusion to a crucifixion of the central character (Gray 1973: 87). 
BERMEJO-RUBIO

completely alone. Jesus is said to have died at the ninth hour (Mark 15:34f and parallels), which means 3 p.m. Gregor dies after the tower clock strikes three in the morning (3 a.m.). The description of the very moment of Gregor's death evokes Jesus' demise according to the Fourth Gospel; compare Kafka's text ("then, without his consent, his head sank down completely, and from his nostrils streamed his last weak breath") ${ }^{26}$ with John 19:30 ("and he bowed his head and gave over the spirit"). Elisabeth Kiefer has also suggested that the episode in which, after Gregor's death, the cleaning woman jabs his corpse with the long broom evokes the passage in the Fourth Gospel (John 19:34) where one of the Roman soldiers stabs Jesus' side with a lance. ${ }^{27}$

All these Christological hints are not surprising. The death of Jesus of Nazareth was interpreted in the Christian tradition (from the Pauline writings on) as a sacrificial and expiatory event. Gregor Samsa has been unmistakably depicted by Kafka, as I have repeatedly remarked, as a victim of his family.

\section{Conclusions}

This survey of the various literary works whose echoes seem to be found in Die Verwandlung does not refute Kafka's originality in the least. If we take into account the most convincing cases made in order to detect the pre-texts and literary echoes in this novella, however, we can draw relevant and unexpected conclusions. Beyond the obvious differences between The Double and David Copperfield, or between the intense eroticism of Venus im Pelz and the deep religious sense of the Gospels, we find in these works striking features in common. First, far from fantasy, monsters and metamorphosis, all of them unmistakably relate stories regarding

26 "Dann sank sein Kopf ohne seinen Willen gänzlich nieder, und aus seinen Nüstern strömte sein letzter Atem schwach hervor." (DL 193-194).

27 "Weil sie [die Bedienerin] zufällig den langen Besen in der Hand hielt, suchte sie mit ihm Gregor von der Tür aus zu kitzeln. Als sich auch da kein Erfolg zeigte, wurde sie ärgerlich und stieß ein wenig in Gregor hinein" (DL 194); see Kiefer 1989: 272. 
Convergent Literary Echoes in Kafka's Die Verwandlung

human beings. Second, every main character is treated in their respective stories, at different degrees, with physical and/or psychological violence, and they accordingly undergo a sharp (physical and/or psychological) degradation; in one sense or another, the protagonists become victims of their fellowmen: Golyadkin is, time and time again, the butt of the jokes caused by his odd behavior, and at least on one occasion he is forced to remain encased in rubbish, as a heap of junk. Severin is turned by Wanda (and also by himself) into a miserable slave. Copperfield and Lemekh are locked up in a room; Jesus is ridiculed and subjected to the most ignominious kind of execution. Furthermore, the process of degradation reaches such an extent, that, in every case, the protagonist is degraded to a subhuman category and compared to an animal: Golyadkin (and Severin) to an insect, Copperfield and Severin to a dog, and Lemekh and Jesus generically to an animal ready to be sacrificed.

The fact that all these texts have these key basic elements in common does not seem to be sheer coincidence. If, as I have argued elsewhere, Kafka has reflected in his story a "corrupt objectivity" and therefore could not directly and explicitly tell the truth about Gregor Samsa, the realization of the fact that the works whose echoes we find in Die Verwandlung are stories about human beings becomes meaningful. This is yet another hint at the way Die Verwandlung should be read. What intertextuality tells us about Gregor Samsa, therefore, is that he is not an animal and a monster, but simply a human being - a human being, however, who is a victim, and accordingly undergoes a strong process of degradation .

All this fits very well with certain indications made by Kafka himself about his plans for publishing his novella with other works of his. In two letters written in April 1913 to Kurt Wolff, Kafka formulated the request of publishing Die Verwandlung, Das Urteil ("The Judgment") and Der Heizer ("The Stoker") together in a book which might be called Die Söhne ("The Sons"). ${ }^{28}$ Two years later,

\footnotetext{
${ }^{28}$ Regarding these works, he states that they "gehören äußerlich und innerlich zusammen, es besteht zwischen ihnen eine offenbare und noch mehr eine geheime Verbindung, auf deren Darstellung durch Zusammen-
} 
BERMEJO-RUBIO

after having written In der Strafkolonie ("In the Penal Colony"), Kafka suggested to the publisher that this new story could be brought together with Die Verwandlung and Das Urteil under the title Strafen ("Punishments"). ${ }^{29}$ It should be clear that, beyond all the other links among them, a basic unifying factor of all these Kafka stories lies in the fact that they all are stories about human beings and about the mistreatments they undergo in their relationships with their fellowmen. Intratextual analysis confirms, therefore, intertextual research.

This is, in my opinion, yet another indication that the prevailing interpretative paradigm of Die Verwandlung - what I have called the "entomological dogma" - should be replaced by another paradigm which seriously takes into account the epistemological, ethical and literary complexity and relevance of this work of Kafka, and, therefore, seriously takes into account the human nature of Gregor Samsa. Only in this way we will finally be able to overcome "the commentators' despair" and to understand, once and for all, this masterpiece of the Western literary canon.

\section{References}

Kafka, F. Drucke zu Lebzeiten (DL), Schriften Tagebücher. Kritische Ausgabe, hrsg. J. Born, G. Neumann, M. Pasley, J. Schillemeit. Frankfurt a.M.: Fischer, 2002.

Kafka, F. Schriften Tagebücher Briefe, hrsg. H.-G. Koch. Frankfurt a.M.: Fischer. Briefe 1900-1912, 1999 (Br I); Briefe 1913 - März 1914, 2001 (Br II).

Kafka, F. Tagebücher (T), hrsg. H.-G. Koch. Frankfurt a.M.: Fischer, 2002. Alt, P.-A. 2008. Franz Kafka. Der ewige Sohn, Eine Biographie. München: C. H. Beck.

Anderson, M. M. 1983. Kafka and Sacher-Masoch. - Journal of the Kafka Society of America 2, 4-19; reprinted in H. Bloom (ed.): Franz Kafka's The Metamorphosis. New York: Chelsea House, 1988, 117-133.

fassung in einem etwa 'die Söhne' betitelten Buch ich nicht verzichten möchte [...] Mir liegt eben an der Einheit der drei Geschichten nicht weniger als an der Einheit einer von ihnen" (Zeller \& Otten 1966: 30).

${ }^{29}$ See Kafka's letter to Georg Heinrich Meyer dating from October 15, 1915 (Zeller \& Otten 1966: 35). 
Convergent Literary Echoes in Kafka's Die Verwandlung

Angress, R. K. 1970. Kafka and Sacher-Masoch. A Note on "The Metamorphosis". - Modern Language Notes 85, 745-746.

Beck, E. T. 1970. Kafkas "Durchbruch". Der Einfluß des jiddischen Theaters auf sein Schaffen. - Basis 2, 204-223.

Beck, E. T. 1971. Kafka and the Yiddish Theater: Its Impact on His Work. Wisconsin: University of Wisconsin Press.

Beicken, P. 1983. Franz Kafka. Die Verwandlung. Stuttgart: Reclam.

Bermejo-Rubio, F. 2010. "Die Lüge wird zur Weltordnung gemacht". Procesos victimarios y distorsión de la objetividad en la obra de Franz Kafka. - Revista de Filología Alemana 18, 135-161.

Bermejo-Rubio, F. 2011. "Diese ernsten Herren...". The solution to the riddle of the three lodgers in Kafka's Die Verwandlung. - Deutsche Vierteljahrsschrift für Literaturwissenschaft und Geistesgeschichte 87, 85-123.

Bermejo-Rubio, F. Die Bedeutsamkeit der Fehlleistungen. Moralische Konflikte in Kafkas Die Verwandlung, forthcoming.

Bermejo-Rubio, F. Grete Samsa's inconsistent speech. The logic underlying the two conflicting versions in Kafka's Die Verwandlung, forthcoming.

Binder, H. 1975. Kafka-Kommentar zu den Sämtlichen Erzählungen. München: Winkler Verlag.

Binder, H. 1983. Kafka. Der Schaffensprozeß. Frankfurt a.M.: Fischer.

Binder, H. 2004. Kafkas "Verwandlung". Entstehung, Deutung, Wirkung. Frankfurt a. M.: Stroemfeld Verlag.

Born, J. 1990. Kafkas Bibliothek. Ein beschreibendes Verzeichnis. Frankfurt a.M.: S. Fischer.

Ehrlich, V. 1956. Gogol and Kafka: A Note on "Realism" and "Surrealism". - Halle, M. ed., For Roman Jakobson. Essays on the Occasion of his Sixtieth Birthday. The Hague: Mouton, 100-108.

Gray, R. 1973. Franz Kafka. Cambridge: Cambridge University Press.

Heselhaus, C. 1952. Kafkas Erzählformen. - Deutsche Vierteljahrsschrift für Literaturwissenschaft und Geistesgeschichte 26, 351-376.

Holland, N. N. 1958. Realism and Unrealism. Kafka's "Metamorphosis". Modern Fiction Studies 4, 143-150.

Kiefer, E. 1989. Theaterspuren im Kafkas Werk. Eine Analyse der Erzählung Die Verwandlung im Hinblick auf ihre theatralen Elemente. Neophilologus 73, 263-280.

Köhnke, K. 1971. Kafkas "Guoter Sündaere”. Zu der Erzählung Die Verwandlung. - Acta Germanica 6, 107-120.

Kuna, F. M. 1972. Art as Direct Vision: Kafka and Sacher-Masoch. Journal of European Studies 2, 237-246. 
BERMEJO-RUBIO

Parry, I. F. 1962. Kafka, Gogol and Nathanael West. - Gray, R. ed., Kafka. A Collection of Critical Essays. New Jersey: Prentice-Hall, 85-90.

Politzer, H. 1962. Franz Kafka. Parable and Paradox. Ithaca: Cornell University Press.

Rudloff, H. 1997. Gregor Samsa und seine Brüder. Kafka, Sacher-Masoch, Thomas Mann. Würzburg: Königshausen \& Neumann.

Spilka, M. 1959. Kafka's Sources for The Metamorphosis. - Comparative Literature 11, 289-307.

Spilka, M. 1963. Dickens and Kafka: A Mutual Interpretation. Bloomington: Indiana University Press.

Sprengel, P. 1995. Kafka und der "wilde Mensch". Neues von Jizchak Löwy und dem jiddischen Theater. - Jahrbuch der Deutschen Schillergesellschaft 39, 305-323.

Wagenbach, K. 1994². Franz Kafka. Bilder aus seinem Leben. Berlin: Verlag Klaus Wagenbach.

Waldeck, P. B. 1972. Kafka's Die Verwandlung and Ein Hungerkünstler as influenced by Leopold von Sacher-Masoch. - Monatshefte für deutschen Unterricht, deutsche Sprache und Literatur 64, 147-152.

Weinberg, K. 1963, Kafkas Dichtungen: Die Travestien des Mythos. Bern \& München: Francke Verlag.

Winkelman, J. 1983. The Liberation of Gregor Samsa. - Whiton, J. \& Loewen, H. eds., Crisis and Commitment: Studies in German and Russian Literature in Honor of J. W. Dyck. Waterloo: University of Waterloo Press, 237-246.

Wokenfeld, S. 1970. Christian Symbolism in Kafka's The Metamorphosis. Studies in Short Fiction 10, 205-207.

Zeller, B. \& Otten, E., eds. 1966. Kurt Wolff: Briefwechsel eines Verlegers 1911-1963. Frankfurt a.M.: Verlag Heinrich Scheffler. 